\title{
Housing and mobility demands of individual households and their life cycle assessment
}

\section{Journal Article}

Author(s):

Saner, Dominik; Heeren, Niko (Di); Jäggi, Boris; Waraich, Rashid A.; Hellweg, Stefanie (D)

Publication date:

2013-06-04

Permanent link:

https://doi.org/10.3929/ethz-b-000065507

Rights / license:

In Copyright - Non-Commercial Use Permitted

Originally published in:

Environmental Science \& Technology 47(11), https://doi.org/10.1021/es304084p 
Subscriber access provided by ETH-Bibliothek

\title{
Article
}

\section{Housing and Mobility Demands of Individual Households and their Life Cycle Assessment}

\author{
Dominik Saner, Niko Heeren, Boris Jäggi, Rashid A Waraich, and Stefanie Hellweg
}

Environ. Sci. Technol., Just Accepted Manuscript • DOI: 10.1021/es304084p • Publication Date (Web): 06 May 2013

Downloaded from http://pubs.acs.org on May 8, 2013

\section{Just Accepted}

"Just Accepted" manuscripts have been peer-reviewed and accepted for publication. They are posted online prior to technical editing, formatting for publication and author proofing. The American Chemical Society provides "Just Accepted" as a free service to the research community to expedite the dissemination of scientific material as soon as possible after acceptance. "Just Accepted" manuscripts appear in full in PDF format accompanied by an HTML abstract. "Just Accepted" manuscripts have been fully peer reviewed, but should not be considered the official version of record. They are accessible to all readers and citable by the Digital Object Identifier (DOI®). "Just Accepted" is an optional service offered to authors. Therefore, the "Just Accepted" Web site may not include all articles that will be published in the journal. After a manuscript is technically edited and formatted, it will be removed from the "Just Accepted" Web site and published as an ASAP article. Note that technical editing may introduce minor changes to the manuscript text and/or graphics which could affect content, and all legal disclaimers and ethical guidelines that apply to the journal pertain. ACS cannot be held responsible for errors or consequences arising from the use of information contained in these "Just Accepted" manuscripts. 
1 Housing and Mobility Demands of Individual

5 a Group for Ecological Systems Design, Institute of Environmental Engineering, ETH

6 Zurich, Schafmattstrasse 6, 8093 Zurich, Switzerland

7 b Transport Planning Group, Institute for Transport Planning and Systems, ETH

8 Zurich, Wolfgang-Pauli-Strasse 15, 8093 Zurich, Switzerland

9

1 Corresponding author. Tel.: +41 4463368 40; fax: +41446331061.

E-mail address: dominik.saner@ifu.baug.ethz.ch (D.Saner). 


\section{Abstract}

13 Household consumption, apart from governmental consumption, is the main driver 14 of worldwide economy. Attached to each household purchase are economic 15 activities along the preceding supply chain, with the associated resource use and 16 emissions. A method to capture and assess all these resource uses and emissions is 17 life cycle assessment.

18 We developed a model for the life cycle assessment of housing and land-based 19 mobility (excl. air travel) consumption of individual households a small village in 20 Switzerland. Statistical census and dwelling register data are the foundations of the 21 model. In a case study performed on a mid-sized community, we found a median 22 value of greenhouse gas emissions of $3.12 \mathrm{t} \mathrm{CO}_{2}$ eq. and a mean value of $4.30 \mathrm{t} \mathrm{CO}_{2}$ 23 eq. per capita and year for housing and mobility. $21 \%$ of the households in the 24 investigated region were responsible for $50 \%$ of the total greenhouse gas 25 emissions, meaning that if their emissions could be halved the total emissions of 26 the community would be reduced by $25 \%$. Furthermore, a cluster analysis 27 revealed that driving factors for large environmental footprints are demands of 28 large living area heated by fossil energy carriers as well as large demands of 29 motorized private transportation.

30 Keywords: Household Environmental Impacts, Life Cycle Assessment, Housing, 31 Mobility, Stochastic Modeling, Cluster Analysis 


\section{TOC/Abstract Art}

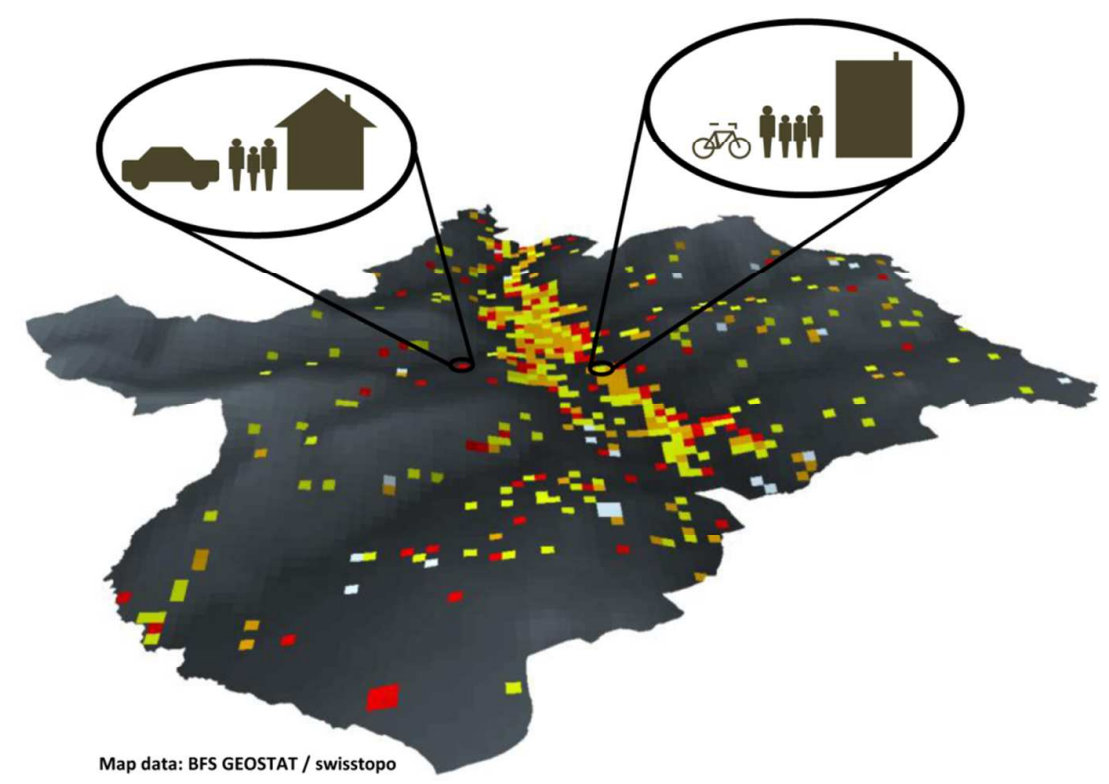


36 1. Introduction

37 On average, $72 \%$ of greenhouse gas (GHG) emissions are directly or indirectly 38 related to household consumption. ${ }^{1}$ While discussions about greenhouse gas 39 reductions often focus on industrial production and energy generation, the 40 discussion about household demand is often left aside. For a serious debate about 41 greenhouse gas emission reduction policies, it is crucial to analyze household 42 consumption patterns, i.e. to quantify the individual demands and environmentally 43 assess their supply.

44 Many municipalities aim for a rational use of energy, the decarbonization of their 45 energy system, an amplified utilization of renewable energy carriers and hence a 46 higher degree of self-sufficiency.2, 3 Thus, there is an interest in household 47 environmental impact studies applicable and valid for specific geographical 48 regions. In the last two decades several studies have tackled the issue of 49 environmental impacts induced by household consumption. Hertwich provides a 50 comprehensive overview. ${ }^{4}$ Commonly, three methodological approaches are 51 applied to measure these impacts: environmentally extended input-output analysis 52 (EEIOA), process-based life cycle assessment (LCA) and hybrid analysis. All three 53 approaches are based on the same four elements: (a) final demand of households, 54 (b) inter-sectorial (or inter-process) input-output relationships, (c) environmental 55 interventions (i.e. emissions and resource use) per sector (or process), and (d) 56 characterizations of environmental interventions. ${ }^{5}$

57 Many studies apply EEIOA. ${ }^{4}$ The final demands of households as well as inter58 sectorial input-output tables (IOT) are provided by national statistical offices. IOT 
59 hold information about aggregated financial transactions (or physical transactions

60 with associated prices) between the sectors of national economies. These financial

61 flows can be linked to environmental interventions (e.g. emissions or resource 62 use) per monetary unit of flow. Environmental interventions are available from 63 sectorial environmental accounts also compiled by national statistical offices. Thus, 64 financial expenditures of households for the output of a specific sector can be 65 environmentally assessed. However, the environmental assessment often covers 66 only national emissions and no upstream emissions due to the import of goods. ${ }^{1,6,7}$ 67 In a bid to overcome this shortcoming, there are trends towards multi-regional $68 \mathrm{EEIOA}^{8}$ and small-scale analyses on municipal level. ${ }^{2}$

69 In hybrid analysis the final demand for domestic output is assessed with EEIOA 70 while upstream activities are assessed with LCA. Jungbluth et al., for example, have 71 performed a tiered hybrid analysis for Switzerland. ${ }^{9}$ They found that an average 72 inhabitant of Switzerland emits 12.5 tons of $\mathrm{CO}_{2}$ equivalents (eq.) per year. In this 73 number they aggregated both domestic emissions (EEIOA) and foreign emissions 74 (LCA). The results yielded by the EEIOA part of the analysis are comprehensive in 75 scope, meaning that they cover all domestic sectorial outputs, for which there is a 76 final household demand. However, generally in hybrid analyses the segmentation 77 of the economy into different sectors is often coarse and the waste treatment 78 sector missing. ${ }^{5}$

79 LCA studies rely on life cycle inventories. They exist for a multitude of 80 consumption related activities and they include upstream processes and waste 81 treatment. Ecoinvent, a well renown life cycle inventory database, includes in its 82 latest version (v2.2) around 100 datasets for agricultural products, 50 datasets for 
83 the generation of heat, and 40 datasets for different means of private 84 transportation. ${ }^{10}$ These numbers will further increase in the future and also cover 85 activities from other areas of consumption, which will allow detailed assessment of 86 household consumption.

87 A process-LCA based analysis is able to differentiate various household 88 consumptions, but the final demands of households have to be determined first 89 before they can then be environmentally assessed. Girod and de Haan extracted 90 the individual final demands of households from the Swiss household income and 91 expenditure survey. ${ }^{11}$ The study resulted in a status quo LCA of the individual 92 yearly consumption of approximately 14,300 households. However, the use of a 93 national sample does not allow for analyzing household consumption on municipal 94 level, which was the aim of this study. Furthermore, we suggest the assessment of 95 environmental impacts of household consumption by modeling individual final 96 demands of households based on register and census data available for all 97 municipalities in Switzerland and employing LCA for the environmental 98 assessment. A modeling approach has the advantages of conducting analyses for 99 any given geographical region in Switzerland as well as of performing 100 improvement studies, for instance, for finding the optimal housing energy supply 101 under regional supply constraints. ${ }^{12}$

102 Tukker and Jansen claim in their review study that housing, mobility and food are 103 responsible for $70 \%$ of the consumption impacts for most environmental impact 104 categories (the rest being mainly clothing, healthcare, education, communication, 105 recreation, and miscellaneous consumption areas). ${ }^{7}$ This figure varies depending 106 on the applied environmental indicator, but holds in general, and has also been 
107 confirmed by Jungbluth et al. ${ }^{9}$ We included two of these three areas of 108 consumption, namely housing and land-based mobility, in our household 109 consumption assessment. The third was included as well in a recent study. ${ }^{13}$

110 The goals of this paper are: (i) to assess the environmental impacts of all individual 111 households on municipal level, (ii) to reveal the distribution of environmental 112 impacts within the community, (iii) to compare the carbon footprint of households 113 against a prospective societal goal of a $1 \mathrm{t} \mathrm{CO}_{2}$ society formulated by Bébié et al.14 114 and in line with the IPCC, $^{15}$ and (iv) to characterize different household 115 consumption patterns that lead to low, medium and high environmental footprints.

\section{$1162 . \quad$ Materials and Methods}

117 2.1. Modeling of final demands of households for life cycle assessment

118 Life cycle assessment is a method to calculate and assess all emissions and 119 resource uses along the supply, use and disposal chains of a product or a service. 120 The computational structure of life cycle assessment is described in the literature 121 as: ${ }^{5}$

$$
\mathbf{h}=\mathbf{Q B A}^{-1} \mathbf{f}
$$

123 Where $\mathbf{h}$ is the impact result, $\mathbf{Q}$ is the characterization matrix, $\mathbf{B}$ is the 124 intervention matrix, $\mathbf{A}$ is the technology matrix, and $\mathbf{f}$ is the final demand 125 vector. ${ }^{16}$ We used this equation to assess the environmental impacts of households. 126 But instead of analyzing the final demand vector $\mathbf{f}$ of an average household, we 127 assessed the final demand vectors $\mathbf{f}_{\mathbf{i}}$ for individual households $i$. The final 
128 demands can therefore be expressed as matrix $\mathbf{F}=\left(\mathbf{f}_{1}|\ldots| \mathbf{f}_{\mathbf{i}}|\ldots| \mathbf{f}_{\mathbf{N}}\right)$ for all $N$

129 households of a region under investigation.

130 Within the consumption area of housing we focused on energy demand for space

131 heating, hot water and electricity as well as demand for building infrastructure.

132 This relates to the United Nations Classification of Individual Consumption

133 According to Purpose (COICOP ${ }^{17}$ ) groups 4.3 and 4.5 and is consistent with other

134 studies that use also this classification system.4, 7 The modeling of land-based

135 mobility consumption covered private traffic demand for leisure and shopping

136 purposes as well as for commuting (COICOP group 7.3), but no air travel. Traffic

137 generated by people at work, for instance by a truck driver, was excluded from the

138 analysis. However, this traffic demand was covered in the background system of

139 the LCA (e.g. the truck transport of light fuel oil from refinery to regional storage).

140 The analysis considers all households resident within the spatial boundaries of any

141 selected Swiss municipality. This spatial scope was chosen because in Switzerland

142 municipalities are the smallest autonomous entity and usually consist of between

143 1,000-10,000 households. The temporal scope was the year 2010. The temporal

144 resolution of the model was on an hourly basis. This gave us the flexibility to

145 aggregate data over any discretionary timeframe (e.g. days, months, seasons, year,

146 or also March 20, 12 PM to June 21, 12 PM).

\section{2.1.1. Housing demand}

148 We used hourly outdoor temperature $\left(T_{a}\right)$ as well as direct horizontal, and diffuse

149 horizontal radiation as inputs for the calculation of space heat demand in 150 buildings. Climatic data was generated with meteonorm v7.18 All residential 
151 buildings situated within the borders of the spatial selection were considered for

152 housing demand modeling. The data describing the buildings was extracted from 153 the Federal Register of Buildings and Dwellings (FRBD). ${ }^{19}$ The FRBD contains up154 to-date data of all buildings and dwellings in Switzerland. The data we used were 155 geographic references (i.e. longitude and latitude, altitude above sea level), 156 building characteristics (i.e. year of construction, number of stories, number of 157 apartments, energy source used for space heating and hot water supply), and 158 characteristics of the building's apartments (i.e. total floor area, number of rooms).

159 We calculated the heating energy demand $\left(Q_{h}\right)$ for each building based on its 160 hourly heat flux balance. Thus, in order to determine $Q_{h}$ we subtracted thermal 161 gains from the losses. As thermal gains we counted solar gains $\left(Q_{S}\right)$ via windows 162 and internal gains due to occupancy $\left(Q_{i P}\right)$ and electricity use $\left(Q_{i E l}\right)$. Thermal losses 163 were losses due to thermal transmission through the building envelope $\left(Q_{T}\right)$ and 164 losses due to ventilation $\left(Q_{V}\right)$. This approach is in accordance with the Swiss 165 standard SIA $380 / 1^{20}$ for thermal energy calculations in buildings published by the 166 Swiss Society of Engineers and Architects (SIA) and is formulated in eq 2.

$$
Q_{h}=\sum_{t=t_{\text {begin }}}^{t_{\text {end }}}\left(Q_{T, t}+Q_{V, t}\right)-\eta_{g} \cdot\left(Q_{s, t}+Q_{i P, t}+Q_{i E l, t}\right)
$$

168 Herein $t$ denotes the hour, $t_{\text {begin }}$ and $t_{\text {end }}$ are the boundaries for the analyzed period 169 and $\eta_{g}$ is the degree of utilization for heat gains, which depends on the thermal 170 storage capacity of the building mass (cf. Supporting Information). For each 171 building we then allocated the heat demand for the whole building to its 172 apartments based on the apartment size. The modeled specific space heat demands 
173 of buildings were compared with average values for different construction periods

174 found in literature. This validation can be found in the Supporting Information.

175 Transmission losses per hour were calculated by means of eq 3 :

176

$$
Q_{T, t}=\left\{\begin{array}{l}
\sum_{j=1}^{n}\left(T_{i, t}-T_{a, t}\right) \cdot A_{j} \cdot U_{j} \\
0 \quad \text { if }\left(T_{i, t}-T_{a, t}\right) \leq 0
\end{array}\right.
$$

177 Where $T_{i}$ is the ambient room temperature (e.g. $20^{\circ} \mathrm{C}$ ), $A_{j}$ is the area and $U_{j}$ is the 178 heat transfer coefficient of building component $j$. The U-values were taken from 179 Wallbaum et al.,21 who reported heat transfer coefficients for four different 180 building components (roof, wall, floor and windows) and distinguished their U181 values according to year of construction of the building and year of renovation of 182 the specific building component. The areas of the four components were calculated 183 from the area of the building surface. The FRBD does not contain information on 184 the shape of the buildings. Hence, each building was simply modeled as a cube with 185 a square base. The base as well as the top area was assumed to be the aggregated 186 apartment area divided by the number of stories. The building surface area was 187 calculated by multiplying the aggregated apartment area with a correction factor 188 and a so-called building envelope factor, ${ }^{22}$ which describes the relationship 189 between total floor area and surface area. Base and top areas were subtracted from 190 the surface area to get the facade area. ${ }^{21}$ The facade was then divided into 191 windows and wall surface by assuming a share of window area of $18 \% .^{23}$

192 The ventilation heat losses per hour were calculated with eq 4. 
193

$$
Q_{V, t}=\left\{\begin{array}{l}
\left(T_{i, t}-T_{a, t}\right) \cdot \dot{V} \cdot \rho_{a} \cdot c_{a} \\
0 \quad \text { if }\left(T_{i, t}-T_{a, t}\right) \leq 0
\end{array}\right.
$$

$194 \dot{V}$ is the hourly air exchange $\rho_{a} \cdot$ is the density of air and $c_{a}$ is the specific heat 195 capacity of air. For buildings with mechanical ventilation, $\dot{V}$ was reduced by a 196 factor describing the efficiency of the heat recovery.

197 The solar gains were calculated with eq 5 :

198

$$
Q_{s, t}=\sum_{j=1}^{n} G_{s, j, t} \cdot A_{w, j} \cdot f_{s, j} \cdot 0.9 \cdot g_{\perp} \cdot f_{F}
$$

199 Where $G_{s, j}$ is the global solar radiation, distinguished for the different facades $j$ 200 of a building (i.e. north, west, south, east, and top), $A_{w, j}$ is the window area, and $201 f_{s, j}, f_{F}$ and $g_{\perp}$ are reduction factors for shading of nearby buildings, window 202 frame and glass properties.

$$
Q_{i, t}=Q_{i P, t}+Q_{i E l, t}
$$

204 For the modeling of internal gains $Q_{i, t}$ we based our calculations on specific values 205 provided by the SIA $380 / 1$ standard. ${ }^{20}$ Electricity demand $Q_{E l}$ was assumed to be $206100 \mathrm{MJ} / \mathrm{m}^{2}$.year for multi-family dwellings and $75 \mathrm{MJ} / \mathrm{m}^{2} \cdot$ year for single family 207 dwellings. ${ }^{20} Q_{i E l, t}$, the hourly internal gains from electricity use, was calculated in 208 eq 7 as:

209

$$
Q_{i E l, t}=Q_{E l} \cdot f_{E l} \cdot A_{E} / 8760 h / y r
$$

$210 f_{E l}$ is a reduction factor that considers the share of electricity that is useful for 211 heating purposes. $A_{E}$ is the heated floor area of the building. 
$212 Q_{i P, t}$ was $0.252 \mathrm{MJ} /$ hour.and person (i.e. $70 \mathrm{~W} /$ person). ${ }^{20}$ This is the thermal

213 power people generate on average when being in a building. The average time 214 people spend in their home is 12 hours per day ${ }^{20}$.

215 Apart from heating and electricity demand, we also calculated the energy demand 216 for the supply of hot water $Q_{w w}$ for each household. Hereby again, we relied on 217 standard values ${ }^{20}$ (i.e. $75 \mathrm{MJ} / \mathrm{m}^{2}$.year for multi-family dwellings and 50 $218 \mathrm{MJ} / \mathrm{m}^{2}$.year for single family dwellings). The total space heating, hot water and 219 electricity demand was then broken down according to the floor area into demand 220 per apartment.

221 Although FRBD is rather comprehensive, some data such as the renovation year of 222 specific building parts, roof inclination, or specific heat supply technology was not 223 available. We therefore assumed that the unknown parameters were stochastic. All 224 of them along with their distribution and uncertainty parameters are stated in the 225 Supporting Information. One of these unknown parameters was the applied heat 226 supply technology for a specific building. The FRBD, however, holds information 227 on the energy source used for space heating and hot water production. It 228 distinguishes between oil, coal, natural gas, electricity, wood, heat pump, solar 229 collectors, and heat from a district network. Wood, for instance, can be further 230 differentiated into heat from logs, chips or pellet incinerating systems. Therefore, 231 we applied stochastic modeling to determine the detailed heating supply 232 technology. From statistical data about wood energy use in Switzerland we derived 233 discrete shares $p\left(x_{i}\right): \square \rightarrow[0,1]$ of log, chips or pellet furnace technologies $234 x_{i}=\{1,2,3\}$. We assigned a random number $Y: \square \rightarrow[0,1]$ to each building. These 
235 random numbers were uniformly distributed among all buildings. Based on $Y$ we

236 determined the furnace technology $x$ of the specific building with:

237

$$
Y=P(x)=\sum_{x_{i} \leq x} p\left(x_{i}\right)
$$

238

239 We used the database ecoinvent ${ }^{10}$ for the life cycle inventory data. Life cycle 240 inventories describe all inputs to and outputs from an economic process. The 241 inputs can be products from other economic processes or resources from the 242 environment. The outputs are direct emissions to environmental compartments 243 and economic goods. Ecoinvent provides datasets covering various supply 244 technologies for each of the aforementioned energy sources. Thus, we extracted 245 the shares of the technologies for a specific energy source from statistics ${ }^{24-26}$ and 246 distributed the technologies stochastically among all buildings using this source. 247 We did that for all energy sources. Then, we linked the space heating and hot water 248 demands per apartment with the respective reference flows of the supplying 249 technology in the technology matrix $\mathbf{A}$. Additionally to the datasets from 250 ecoinvent, we also established new datasets that we included in the technology 251 matrix. The life cycle inventory of heat from brine-water heat pump, was taken 252 from Saner et al. ${ }^{27}$ Regionalized electricity supply datasets were modeled 253 according to the respective declaration by the local electricity utility and linked to 254 the household's direct electricity demand and the heating technology's electricity 255 demand. 
256 2.1.2. Land-based mobility demand

257 Land-based mobility demand was calculated based on the output from an agent258 based transport simulation called MATSim. ${ }^{28}$ An agent-based model was employed 259 because it is able to model individual demands for a specific geographic region. 260 MATSim is a modeling environment, which allows for simultaneously simulating 261 land-based mobility patterns of millions of so-called agents. Agents represent 262 inhabitants of a municipality, region or country. MATSim has been implemented 263 and validated for Switzerland and is able to model traffic behavior of Swiss 264 inhabitants for an average workday. ${ }^{29,} 30$ At the moment no weekend or intra-week 265 model for Switzerland is implemented in MATSim. Therefore, we approximated 266 yearly mobility patterns with 365 workdays. As the average travel distance for 267 weekends equals the average travel distance for work days this assumption is 268 justifiable. ${ }^{31}$

269 MATSim simulates the agents' workday mobility patterns based on the agents' 270 daily plans. These plans are defined by the locations where agents live, work, and 271 spend time for shopping and leisure. Swiss National Census $2000^{32}$ and micro 272 census $2005^{33}$ (micro census is a census about the land-based mobility behavior of 273 people) data are the statistical basis for the generation of a synthetic population of 274 agents and their daily activity plans. Agents have characteristics like age, gender, 275 and education and are grouped together in households with specific household 276 characteristics like income, geographic location and types of fuel (i.e. petrol, diesel 277 or other), which are derived from the Swiss National Census $2000^{32}$. The daily 278 activities of agents are defined by the agents' characteristics, census data about 279 their place of work as well as spatial information about schools and shopping 
280 opportunities in their vicinity. For an in-depth description of the MATSim 281 modeling framework and its application to Switzerland we refer to the work of 282 Balmer et al. ${ }^{28}$

283 MATSim uses an iterative approach, which is based on a co-evolutionary 284 algorithm. ${ }^{34}$ This means, after one traffic simulation for a day, the performance of 285 each agent is scored using a utility function, e.g. lower travel time resulting in 286 higher score. For the next iteration the current plan can be adapted or a previously 287 executed plan reselected for execution. Only a limited set of plans is kept within 288 the memory of the agent, from which plans with higher score have a higher chance 289 of reselection, while bad plans are deleted over time (see Supporting Information). 290 This corresponds to the survival of the fittest in a co-evolutionary algorithm. As the 291 iterations continue, the process approaches equilibrium. This means, at this point 292 the utilities of agents only change marginally between iterations. The output data 293 from a MATSim simulation contains the details of selected plans together with 294 detailed output of the traffic simulation for each agent. These plans state when 295 agents left a specific location, for how long and how far they drove and what traffic 296 mode they used.

297 The micro census, the statistical basis of MATSim, only covers land-based 298 transportation modes. Thus, only land-based mobility patterns can be simulated by 299 MATSim. MATSim distinguishes the following four travel modes: car, public 300 transport, bicycle, and walk. Motorcycles are subsumed under the category car. 301 Hence, we calculated the mobility demand (in terms of travelled kilometers) of 302 each agent and each traffic mode and aggregated the traffic demand on household 303 level. 
304 Household data from the Swiss National Census $2000^{32}$ is subject to data 305 protection thus its geographic reference does exactly coincide with the geographic 306 reference of building in the FBDR. However, the geographic reference of 307 households is accurate within a $100 \times 100 \mathrm{~m}$ grid resolution. Thus, each household 308 was assigned to the nearest building and within the building to an appropriate 309 apartment, i.e. an apartment with enough rooms to hold all members of the 310 household. If an apartment was already occupied by another household then our 311 model looked for another available apartment. Hereby, double occupancy was 312 avoided. After this step, we knew for each household $i$ the housing and land-based 313 mobility demand. This was then compiled in a final demand vector $\mathbf{f}_{\mathbf{i}}$. The non314 zero values of the vector represented the demand for a reference product supplied 315 by a process stored in the technology matrix A. Final household demand vectors 316 were merged into the final demand matrix $\mathbf{F}$ and impact results $\mathbf{h}$ calculated with 317 eq 1.

\section{$318 \quad$ 2.2. Uncertainty analysis}

319 The FRBD and MATSim did not provide all information needed for the modeling. 320 For instance, we had no information if the windows in a certain building had 321 already been replaced since the time of construction. However, we had the data on 322 the probability that windows had been replaced and the according U- and g-values 323 of the replaced windows. Thus to compensate for missing information in the data 324 sources like the exact assignment of households to apartments we employed 325 stochastic modeling. A comprehensive list of uncertain model parameters can be 326 found in the Supporting Information. Uncertainty analysis was performed by 327 employing Monte Carlo simulation. The simulation was run 1,000 times. This 
328 means that impact results from housing and mobility were calculated each time

329 with different input values. Sample values for the Monte Carlo simulation were 330 obtained with the Latin hypercube sampling method. ${ }^{35}$ After the simulation there 331 were 1,000 samples of impact results for each of the analyzed households. 332 Household impact results within one sample were not independent from each 333 other due to various modeling constraints. For example, two households could not 334 share the same apartment. We tested, whether the 1,000 samples of household 335 impact results were samples of the same statistical population by means of the 336 Kruskal-Wallis-test. ${ }^{36}$ We calculated the median impact result for each sample and 337 then calculated the median, the $2.5^{\text {th }}$ and $97.5^{\text {th }}$ percentiles of these 1,000 median 338 values. This led to the median sample and the samples representing the $2.5^{\text {th }}$ and $33997.5^{\text {th }}$ percentiles that are presented in Supporting Information.

\section{$340 \quad$ 2.3. Cluster analysis}

341 The modeling resulted in impact results for several thousand households of a 342 region. According to their environmental footprints we categorized the households 343 in four groups. Cluster analysis (CA) for each group of households then allowed for 344 further data reduction without losing information on differences in the 345 households' environmental footprints. We used hierarchical clustering applying 346 Ward's method as linkage criterion. ${ }^{37}$ The cluster analysis started by treating 347 individual households as single clusters. Then, always two clusters were merged 348 into one bigger cluster based on the smallest proximity measure. This procedure 349 was performed until only 3 to 4 clusters per group remained. As proximity metric 350 we used the squared Euclidean distance, which is the sum of the square differences 351 between the elements of two vectors. ${ }^{37}$ The shorter this distance the closer two 
352 clusters are. The two clusters with the shortest distance were then merged. As

353 parameters for the cluster analysis we used aside from life cycle impact results the

354 following household characteristics:

355 - Size: Number of household members.

356 - Income: Household income per month. Income is categorized into 10

357 categories. 1 equals 0-1,999 CHF/month, 2 equals 2000-2,999 CHF/month

358 and so forth. 10 equals 10,000 CHF /month and more.

359 - Age of the oldest household member.

360 - Age of the youngest household member.

361 - Highest education: The highest educational level that was achieved by one

362 of the household members. Education is categorized in 10 categories. The 363 categories range from no education (1) to university degree (10).

364 Additionally, average apartment area per person, and average number of 365 apartments per building were calculated per cluster.

\section{2.4. Case study}

367 To illustrate the application of the household consumption LCA, we performed a 368 case study for Wattwil, a municipality located in the eastern part of Switzerland in 369 the canton of St. Gallen. Wattwil has around 8,000 inhabitants living in 3,238 370 households and is the capital of the Toggenburg district.

371 The environmental impacts of each household were assessed on a yearly basis. Life 372 cycle greenhouse gas emissions ${ }^{38}$ were used as the main environmental indicator. 373 This method was chosen as it enables the comparison with other studies. ${ }^{39}$ 374 Although we are presenting the results only in $\mathrm{CO}_{2}$ equivalent (eq.) emissions, our 
375 model is capable of applying all common life cycle impact assessment methods

376 provided by ecoinvent ${ }^{10}$ (e.g. $\mathrm{ReCiPe}^{40}$ midpoint indicators) to calculate various

377 environmental impacts of households.

\section{3. Results and Discussion}

379 The life cycle assessment of households' consumption was performed for the 380 reference year 2010. Figure 1a shows the median life cycle greenhouse gas (GHG) 381 emissions in metric tons for housing and land-based mobility consumption of 3823,238 individual households. The results were normalized by the number of 383 household members. We found by applying the Kruskal-Wallis-test that there was 384 no significant difference between the 1,000 different samples calculated with 385 Monte Carlo simulation (see Supporting Information). Thus, the results of the 386 median sample are representative and suitable for further discussion. The blue 387 bars in Figure 1a represent GHG emissions induced due to commuting, shopping 388 and leisure purposes by different means of land-based traffic modes and the use of 389 their infrastructure. GHG emissions induced by space heating, hot water, electricity 390 consumption and building infrastructure are depicted in yellow. The resulting GHG 391 emissions are normalized by the number of people living in the household and 392 ranked from the lowest to the highest emitters. Impact results for $\mathrm{ReCiPe}^{40}$ 393 midpoint categories and Ecological Scarcity ${ }^{4}$ are reported in the Supporting 394 Information. 

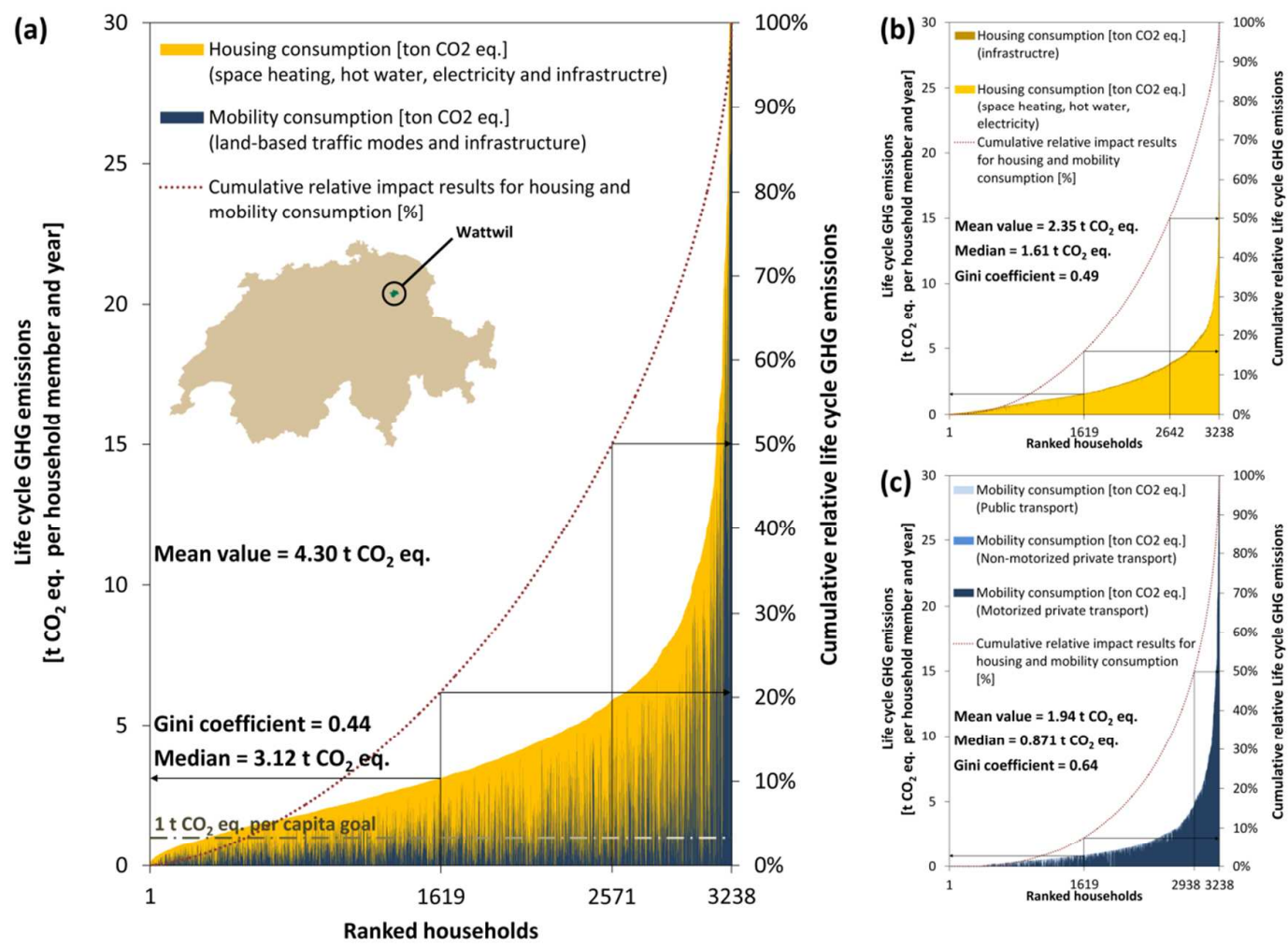

Figure 1. Life cycle greenhouse gas emissions of individual households in Wattwil (CH) in the year 2010

397 induced by housing and mobility (a) and housing (b) and mobility (c) alone. The impact results per household have been normalized by the respective number of household members and ranked from smallest to largest value. The included map shows the size of Wattwil and its location within Switzerland (map data: BFS GEOSTAT / swisstopo).

401

402 The median value for life cycle GHG emissions over all 3,238 households was 403 calculated as 3.12 t $\mathrm{CO}_{2}$ eq. per person and year. Hence, 50\% of households emit 404 less and the other $50 \%$ emit more than this value. The mean value is $4.30 \mathrm{t} \mathrm{CO}_{2}$ eq. 405 per person, which is $10 \%$ lower than the Swiss average for housing and land-based 406 mobility consumption in 2005 (4.76 $\mathrm{t} \mathrm{CO}_{2}$ eq. per person). ${ }^{39}$ The distribution of 407 environmental impacts in the municipality is skewed to the right. Thus, more households generate less GHG emissions than the mean value. A Gini inequality 
409 index $42 G$ of 0.44 was calculated for Wattwil. A $G$ of 1 would mean total 410 inequality and a $G$ of 0 would mean total equality among the impact results of the 411 different households. For calculation of $G$ see the Supporting Information. The 412 findings suggest that GHGs are not emitted equally and that a small share of 413 households in Wattwil is responsible for a large amount of GHG. This is supported 414 by the cumulative relative impact results also presented in Figure 1a, for which it is 415 shown that at the lower end $50 \%$ of the households are responsible for only 416 around one fifth of the housing and mobility impacts, but that the $20 \%$ of the 417 households with the largest impacts emit $50 \%$ of GHGs. The results in Figure $1 \mathrm{a}$ 418 also indicate that already around $12.4 \%$ of Wattwil inhabitants (311 households) 419 comply with a $1 \mathrm{t} \mathrm{CO}_{2}$ eq. per capita goal so far. However, if we added more 420 consumption categories, the number of inhabitants complying with the goal would 421 of course decrease.

422 Figure $1 \mathrm{~b}$ and $\mathrm{c}$ show the ranked household impacts differentiated for housing and 423 mobility. The impacts for the two consumption areas are further distinguished into 424 housing operation (space heating, hot water, and electricity) and building 425 infrastructure, and motorized private, non-motorized private and public 426 transportation, respectively. Building infrastructure amounts on average only to $4275.8 \%$ of total housing impacts. This means that the building stock in Wattwil is 428 rather old, as for new buildings the impacts of infrastructure can strongly influence 429 the housing impacts. ${ }^{43}$ The Gini coefficients are 0.49 for housing and 0.64 for 430 mobility. This means that housing impacts are more equally distributed among 431 households than mobility impacts. Housing is the main driver for the carbon432 intensity of households. Another thing that can be observed is that by aggregating 
433 the impacts of both consumption categories we find a more equal impact 434 distribution among the low-emitting households.

435 As the geographical references of the households are known, we are able to 436 present the magnitude of household-specific consumption impacts at the place of 437 residence of the respective households (see Figure 2). Thereby, it is possible to 438 identify areas of a municipality, where high-impacting households reside. The 439 maps were rasterized with a cell size of $100 \times 100 \mathrm{~m}$ and the environmental impacts 440 within one raster cell were averaged for the reason of data privacy protection. The 441 map on the left hand side shows the spatial distribution of life cycle GHG emissions 442 induced by housing, the map on the right hand side shows the same for mobility. 443 The results are graduated into four classes, meaning that the raster cells are 444 categorized into four groups according to their average impact per raster cell. The 445 groups were derived by investigating the impact result distribution depicted in 446 Figure 1a. The groups consist of households that are below 1 ton $\mathrm{CO}_{2}$ eq. per capita 447 and year, households that emit less than the median value (i.e. $50^{\text {th }}$ percentile or $44820 \%$ of cumulative emissions), households that contribute between $20 \%$ and $50 \%$ 449 and households that contribute more than $50 \%$ to the cumulative impact result 450 (i.e. the $80^{\text {th }}$ percentile).

451 Wattwil is a center for the surrounding rural region. ${ }^{44}$ This is also reflected in the 452 spatial distribution of households, which shows that most households are situated 453 along a main street crossing from North to South. 

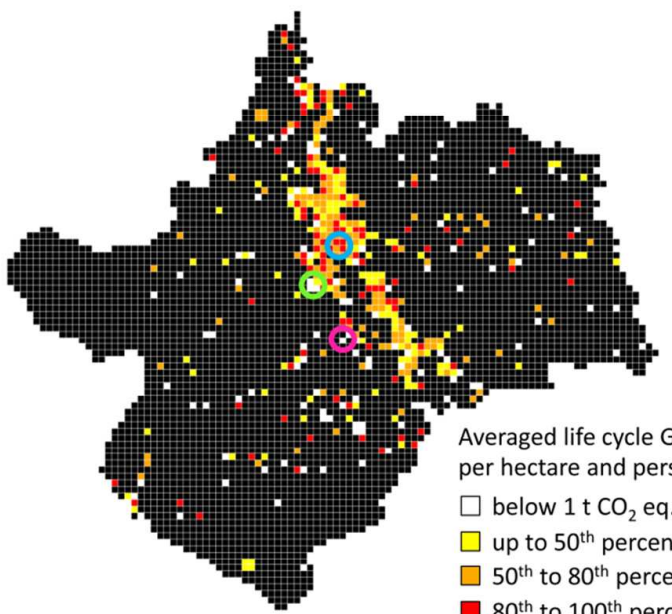

$+2$

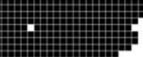

n

Averaged life cycle GHG emissions per hectare and person:

$\square$ below $1 \mathrm{t} \mathrm{CO}_{2}$ eq.

$\square$ up to $50^{\text {th }}$ percentile

$\square 50^{\text {th }}$ to $80^{\text {th }}$ percentile

$\square 80^{\text {th }}$ to $100^{\text {th }}$ percentile

Housing consumption

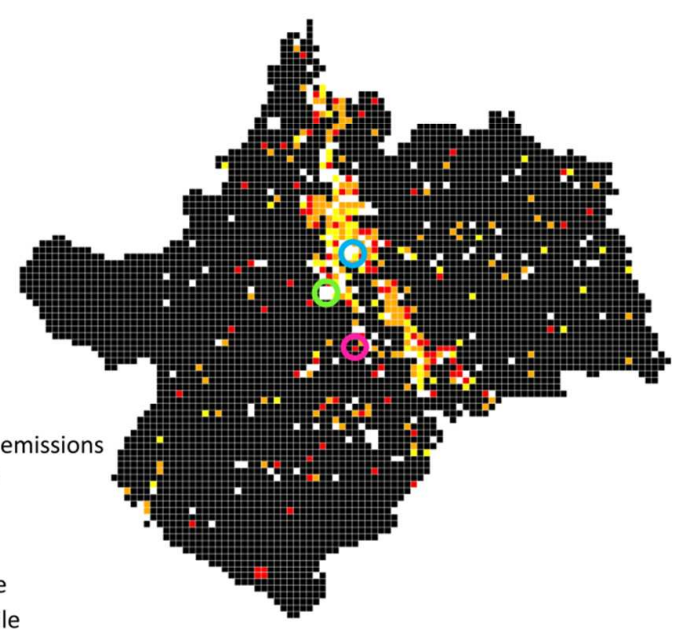

Mobility consumption
455

Figure 2. Rasterized maps of Wattwil (map data: BFS GEOSTAT / swisstopo) showing averaged life cycle GHG emissions per hectare graduated into four classes. Blue and pink circles indicate areas, where housing and mobility impacts are significantly different. Green circle indicate areas, where housing and mobility impacts are both on a similar level.

The spatial distribution of impacts shows that for some areas in the municipality we find differences between the impacts of housing and land-based mobility. One of these areas is marked by a bright blue circle. Here we find households that belong mainly to the $3^{\text {rd }}$ and $4^{\text {th }}$ group in terms of GHG emissions from housing, but to $1^{\text {st }}$ and $2^{\text {nd }}$ group in terms of mobility. The finding suggests that these 
472 we also find households whose environmental performances are similar for both 473 areas of consumption. One such example is marked with a green circle. These 474 households are below the $1 \mathrm{t} \mathrm{CO}_{2}$ eq. goal in both consumption categories. Possible 475 trade-offs were not further investigated.

476 The question about the reliability of the aforementioned findings is of utmost 477 importance. As we performed stochastic modeling of the household demands we 478 were able to identify the median as well as the $95 \%$-confidence interval of impact 479 results. We found that the distributions of impact results among the households 480 stay constant over the whole range of uncertainty samples (see Supporting 481 Information).

482 We used the aforementioned grouping of households for subsequent cluster 483 analyses. Here the groups are denoted as A, B, C, and D. Applying cluster analyses 484 we were able to reduce several hundred individual households to 3-4 clusters per 485 group. The results of the CA are presented in Table 1. We find three meaningful 486 clusters in group A, four clusters in group B, four in group C, and three clusters in 487 group D.

Table 1. Clusters of similar households with their respective household characteristics, greenhouse gas 489 emissions per capita and year induced by housing and land-based mobility as well as the distance to 490 city center. Values are presented as average values of cluster.

\begin{tabular}{|c|c|c|c|c|c|c|c|c|c|c|c|c|}
\hline $\begin{array}{l}\text { Cluster } \\
\text { name }\end{array}$ & $\begin{array}{l}\text { Cluster } \\
\text { size } \\
\text { [No. of } \\
\text { househ } \\
\text { old] }\end{array}$ & $\begin{array}{r}\text { No. of } \\
\text { persons per } \\
\text { household }\end{array}$ & $\begin{array}{r}\text { Household } \\
\text { income } \\
\text { category }\end{array}$ & $\begin{array}{r}\text { Max. Age } \\
\text { of the } \\
\text { oldest } \\
\text { person in } \\
\text { the } \\
\text { household }\end{array}$ & $\begin{array}{r}\text { Min. Age of } \\
\text { the } \\
\text { youngest } \\
\text { person in } \\
\text { the } \\
\text { household }\end{array}$ & $\begin{array}{r}\text { Highest } \\
\text { education } \\
\text { level } \\
\text { achieved by } \\
a \\
\text { household } \\
\text { member } \\
\end{array}$ & $\begin{array}{r}\text { Housing } \\
\text { operation } \\
\text { impacts } \\
\text { [t } \mathrm{CO}_{2} \text { eq. } \\
\text { per person } \\
\text { and year] }\end{array}$ & $\begin{array}{r}\text { Building } \\
\text { infra- } \\
\text { structure } \\
\text { impacts } \\
{\left[\mathrm{kg} \mathrm{CO} \mathrm{CO}_{2} \mathrm{eq} .\right.} \\
\text { per person } \\
\text { and year] } \\
\end{array}$ & $\begin{array}{r}\text { Mobility } \\
\text { impacts } \\
{\left[\mathrm{t} \mathrm{CO}_{2} \text { eq. }\right.} \\
\text { per person } \\
\text { and year] }\end{array}$ & $\begin{array}{r}\text { Apart- } \\
\text { ment } \\
\text { area } \\
{\left[\mathrm{m}^{2} \text { per }\right.} \\
\text { person] }\end{array}$ & $\begin{array}{r}\text { No. of } \\
\text { apart- } \\
\text { ments } \\
\text { per } \\
\text { building }\end{array}$ & $\begin{array}{r}\text { Distance } \\
\text { to city } \\
\text { center } \\
{[\mathrm{km}]} \\
\end{array}$ \\
\hline A1 & 110 & 1.5 & 3 & 70 & 66 & 3 & 0.4 & 92 & 0.2 & 82 & 3 & 1.13 \\
\hline A2 & 122 & 4.6 & 5 & 46 & 10 & 5 & 0.2 & 22 & 0.5 & 23 & 3 & 1.36 \\
\hline A3 & 79 & 3.5 & 5 & 38 & 14 & 3 & 0.5 & 32 & 0.2 & 36 & 8 & 1.39 \\
\hline B1 & 172 & 1.6 & 4 & 55 & 51 & 4 & 0.5 & 93 & 1.3 & 78 & 3 & 1.25 \\
\hline B2 & 365 & 3.3 & 3 & 40 & 14 & 4 & 1.3 & 34 & 0.7 & 34 & 7 & 1.33 \\
\hline
\end{tabular}




\begin{tabular}{lllllllllllll} 
B3 & 347 & 4.6 & 7 & 45 & 10 & 5 & 0.7 & 25 & 1.2 & 24 & 6 & 1.37 \\
B4 & 424 & 2.0 & 5 & 67 & 57 & 4 & 1.7 & 46 & 0.4 & 46 & 9 & 1.06 \\
\hline C1 & 143 & 2.0 & 6 & 56 & 46 & 6 & 3.0 & 53 & 1.1 & 60 & 8 & 1.06 \\
C2 & 297 & 1.4 & 3 & 73 & 71 & 3 & 3.5 & 71 & 0.7 & 75 & 8 & 1.11 \\
C3 & 295 & 3.5 & 5 & 46 & 19 & 5 & 1.2 & 31 & 3.0 & 34 & 7 & 1.31 \\
C4 & 216 & 1.3 & 3 & 40 & 38 & 4 & 3.1 & 116 & 1.1 & 91 & 7 & 1.12 \\
\hline D1 & 305 & 1.2 & 3 & 62 & 61 & 3 & 5.6 & 101 & 3.2 & 111 & 9 & 1.17 \\
D2 & 181 & 3.1 & 6 & 49 & 24 & 5 & 2.6 & 44 & 6.4 & 50 & 9 & 1.20 \\
D3 & 182 & 1.3 & 3 & 34 & 31 & 4 & 6.2 & 79 & 8.1 & 100 & 7 & 1.07 \\
\hline
\end{tabular}

492 The clusters are ranked in ascending order according to their total impacts (i.e. the 493 sum of housing operation, building infrastructure and mobility impacts). The 494 cluster sizes range between 79 and 424. For each cluster we also calculated the 495 average of the distance between each household of the cluster and city center.

496 The first group (A) of clusters represents 9.5\% of all households in Wattwil and 497 comprises households that emit below 1 ton of GHGs per person and year for land498 based mobility and housing. Cluster A1 consists of small households of elderly 499 people and clusters A2 and A3 are formed by families with children. The 500 apartment area per person is rather small (average for group A is $47 \mathrm{~m}^{2}$ per 501 person) and the buildings are, judged by the low infrastructure emissions (i.e. 502 average for the group is $49 \mathrm{~kg} \mathrm{CO}_{2}$ eq. per person and year), rather old. The 503 impacts from space heating, hot water and electricity consumption (i.e. housing 504 operation) are below $0.5 \mathrm{t} \mathrm{CO}_{2}$ eq. This means that households of these clusters live 505 in more poorly insulated buildings than households of clusters from other groups 506 (building infrastructure emissions for group C $66 \mathrm{~kg} \mathrm{CO}_{2}$ eq. per person and year, 507 and group $\mathrm{D} \mathrm{kg} \mathrm{CO} 2$ eq. per person and year), but the apartments are heated by 508 low GHG emitting heating systems (share of wood heating system in group A is $50957 \%$, heat pumps 6\%, and electricity 9\%) and they only use a limited living area. 
510 Impacts from mobility are very low, due to low demand for motorized private

511 transportation and only moderate demand for public and non-motorized private

512 transportation. The group not only comprises households of elderly people, who

513 tend to have lower demands of mobility, but also clusters of young families. This

514 finding suggests that these households have either short or no commuting 515 distances (e.g. farmers).

516 Group B is formed by households that emit less GHGs than the median but more 517 than 1 ton. Also here we find clusters of singles/couples and families. Each cluster 518 is below 1 ton GHG emissions in one of the two consumption areas. This means 519 that they either perform very well in housing (B1, B3) or mobility (B2, B4). The 520 rather moderate emissions from housing stem from a higher share of wood and 521 natural gas fueled ( $14 \%$ and $36 \%$, respectively) heating systems and the small 522 living area per person, which on average for the group is even slightly smaller $523\left(44 \mathrm{~m}^{2}\right)$ than for the clusters in group A. Most clusters have moderate demand for 524 motorized private transportation or high demand for public transportation. 525 Mobility impacts are highest for cluster B1. They are even higher as for three 526 clusters of group C, and only cluster C3 has higher impacts for mobility.

527 Group C consists of three clusters (C1, C2 and C4) with GHG emissions dominated 528 by housing operation and one cluster (C3) with high impacts from mobility. The 529 emissions of one category are often two to three times higher than the emissions of 530 the other.

531 Group D is formed by households that consume large amounts of fossil fuel for 532 heating (share of oil heating approx. 66\%) and transportation purposes. This 533 group is responsible for $50 \%$ of the cumulative GHG emissions induced by 
534 households in the case study municipality, meaning that if their impacts could be 535 halved, the cumulative impacts of Wattwil would be reduced by $25 \%$. The 536 households in group D have similar properties as the households in the other 537 groups (i.e. single/couples and families with grown-up children). However, their 538 emissions are high from housing and also from mobility. Clusters D1 and D3 have 539 the highest emissions for space heating, hot water and electricity consumption, but 540 also among the highest for building infrastructure, which suggests that the 541 buildings inhabited by the people in these clusters are fairly well insulated. 542 However, the emissions from housing are high, because the two clusters use large 543 apartment areas (on average $92 \mathrm{~m}^{2}$ per person) and heat with fossil fuels.

544 In our analyses we were only examining the life cycle GHG emissions induced by 545 household consumptions. Thus, our conclusions are only valid for this impact 546 category. However, under this constraint and for the situation in Wattwil, we can 547 conclude for housing that we can only achieve low impacts by a combination of 548 small demand and almost low-carbon supply (cf. group A and B of clusters). 549 Therefore buildings should be refurbished and living area per capita should be 550 kept small. Wood heating and heat pump systems should be installed. The 551 disadvantage of the former is the high emission loads of particulate matter and 552 that of the latter is the augmented use of electricity. These drawbacks could be 553 mitigated by installing efficient, centralized systems connected to the buildings via 554 district grid. ${ }^{46}$ For today's land-based mobility we cannot switch immediately to a 555 low-carbon supply. Alternatives to internal combustion engines like plug-in hybrid, 556 battery electric or fuel cell cars are now made ready for the market, but still have 557 deficiencies in range and necessary infrastructure. Thus so far, impacts from 
558 mobility can only be significantly reduced by a reduction of motorized private

559 transportation and a moderate use of public transport. However, this is often not

560 possible due to long commuting distances. Hence, for a long-term GHG reduction

561 strategy it is of great importance to bring living and working places closer 562 together.

\section{4. Outlook}

564 There are also other factors than housing and mobility contributing to overall 565 household environmental impacts. Food and clothing are the third and fourth most 566 important consumption categories and further work should focus on implementing 567 household demand models for them. Hence, this would lead to a more complete 568 LCA-based picture of household environmental impacts.

569 More Swiss municipalities should be investigated in the way we demonstrated for 570 Wattwil. This would allow comparing the different distribution profiles of 571 household environmental impacts against each other. Low-impacting communities 572 could be identified and factors like short commuting distances could be derived 573 from the analysis of their community structure. The results should be used to 574 establish long-term roadmaps that focus on promoting these factors.

575 The presented modeling approach can furthermore be used for scenario analysis of 576 changes in housing and mobility demand (e.g. better insulation of buildings, 577 introduction of electric cars, etc.) as well as for the optimization of mobility or 578 housing supply under different regional supply constraints. ${ }^{12}$ 
580 Details on uncertainty considerations and further impact assessment results can

581 be found in the Supporting Information. This information is available free of charge

582 via the Internet at http://pubs.acs.org/.

\section{6. Acknowledgements}

584 We would like to thank Bernhard Steubing for his valuable comments and 585 Catherine Raptis for the English proofreading. This work was carried out within 586 THELMA (technology-centered electric mobility assessment, www.thelma587 emobility.net), a project funded by the Competence Center for Energy \& Mobility 588 (CCEM) and swisselectric Research.

1. Hertwich, E. G.; Peters, G. P., Carbon footprint of nations: a global, trade-linked analysis. 591 Environmental Science \& Technology 2009, 43, 6414-20.

$592 \quad 2 . \quad$ Larsen, H. N.; Hertwich, E. G., The case for consumption-based accounting of greenhouse 593 gas emissions to promote local climate action. Environmental Science \& Policy 2009, 12, 791-798.

$594 \quad 3 . \quad$ Schlegel, M.; Trutnevyte, E.; Scholz, R. W., Patterns of residential heat demand in rural 595 Switzerland. Building Research \& Information 2012, 40, 140-153.

5964 4. Hertwich, E. G., The Life Cycle Environmental Impacts of Consumption. Economic Systems 597 Research 2011, 23, 27-47.

$598 \quad 5 . \quad$ Heijungs, R.; Suh, S., The Computational Structure of Life Cycle Assessment. 1 ed.; Springer: 5992002.

$600 \quad 6 . \quad$ Cicas, G.; Hendrickson, C. T.; Horvath, A.; Matthews, H. S., A Regional Version of a US 601 Economic Input-Output Life-Cycle Assessment Model. International Journal of Life Cycle Assessment $602 \quad 2007,12,365-372$.

603 7. Tukker, A.; Jansen, B., Environmental impacts of products. Journal of Industrial Ecology $6042006,10,159-182$.

605 8. EXIOBASE consortium EXIOBASE. http://www.exiobase.eu/products (20 September),

$6069 . \quad$ Jungbluth, N.; Stucki, M.; Leuenberger, M.; Nathani, C. Environmental Impacts of Swiss 607 Consumption and Production. A combination of input-output analysis with life cycle assessment; 1111; 608 Federal Office for the Environment FOEN: Ittigen $(\mathrm{CH}), 2011$.

609 10. ecoinvent Centre ecoinvent data v2.2. http://www.ecoinvent.org/database/ (16 July),

610 11. Girod, B.; De Haan, P., GHG reduction potential of changes in consumption patterns and 611 higher quality levels: Evidence from Swiss household consumption survey. Energy Policy 2009, 37, 612 5650-5661. 
613 12. Saner, D.; Vadenbo, C. O.; Steubing, B.; Hellweg, S., An optimization extension for the 614 matrix-based life cycle model - Minimizing the environmental impacts from household energy 615 supply. in submission.

616 13. Saner, D.; Stoessel, F.; Jäggi, B.; Juraske, R.; Hellweg, S., FoodPrints of households. in 617 submission.

618 14. Bébié, B.; Dietrich, P.; Eckmanns, A.; Egger, K.; Frischknecht, R.; Cherix, G.; Gugerli, H.; 619 Hartmann, C.; Lenzlinger, M.; Schneider, S.; Stulz, R.; Vogel, U. 2000-Watt-Gesellschaft Bilanzierungskonzept; Fachstelle 2000-Watt-Gesellschaft: Zurich (CH), 2012.
15. IPCC
Working
Group
III:
Mitigation.

http://www.ipcc.ch/ipccreports/tar/wg3/index.php?idp=57 (16 July),

16. Heijungs, R., Sensitivity coefficients for matrix-based LCA. The International Journal of Life Cycle Assessment 2010, 15, 511-520.

17. United Nations Statistics Division COICOP (Classification of Individual Consumption According to Purpose). http://unstats.un.org/unsd/cr/registry/regcst.asp?Cl=5 (8 May),

18. METEOTEST meteonorm $v 7$, Berne (CH), 2012.

19. BFS Eidgenössisches Gebäude- und Wohnungsregister; Bundesamt für Statistik BFS: Neuchâtel (CH), 2010.

20. Swiss Society of Engineers and Architects Thermische Energie im Hochbau; 380/1; SIA: 2009.

21. Wallbaum, H.; Heeren, N.; Jakob, M.; Martius, G.; Gross, N. Gebäudeparkmodell; Zurich (CH), 2010.

22. Dettli, R.; Bade, S.; Baumgartner, A.; Bleisch, M. Vorstudie zur Erhebung von Energiekennzahlen von Wohnbauten; Bundesamt für Energie BFE: Ittigen (CH), 2007.

23. Jagnow, K.; Horschler, D.; Wolff, S., Die neue Energieeinsparverordnung 2002. DWD-Verlag: Köln (DE), 2002.

638 24. Fachvereinigung Wärmepumpen Schweiz FWS Wärmepumpen-Statistiken. http://www.fws.ch/statistiken.html (16 July),

25. Hostettler, T. In Markterhebung Sonnenenergie 2009, Ittigen, CH, 2010; Ittigen, CH, 2010.

26. Primas, A.; Cloos, L.; Kessler, F. M. Schweizerische Holzenergiestatistik - Erhebung für das Jahr 2010; Ittigen (CH), 2011.

27. Saner, D.; Juraske, R.; Kübert, M.; Blum, P.; Hellweg, S.; Bayer, P., Is it only CO2 that matters? A life cycle perspective on shallow geothermal systems. Renewable and Sustainable Energy Reviews 2010, 14, 1798-1813.

28. Balmer, M.; Axhausen, K. W.; Nagel, K., Agent-Based Demand-Modeling Framework for Large-Scale Microsimulations. Transportation Research Record 2006, 1985, 125-134.

29. Meister, K.; Balmer, M.; Ciari, F.; Horni, A.; Rieser, M.; Waraich, R. A.; Axhausen, K. W. In Large-scale agent-based travel demand optimization applied to Switzerland, including mode choice, 12th World Conference on Transportation Research, Lisbon (PT), 2010; Lisbon (PT), 2010.

30. Meister, K.; Rieser, M.; Ciari, F.; Horni, A.; Balmer, M.; Axhausen, K. W., Anwendung eines agentenbasierten Modells der Verkehrsnachfrage auf die Schweiz. Strassenverkehrstechnik 2009, 53, (5), 1-22.

31. BFS Mobilität in der Schweiz - Ergebnisse des Mikrozensus Mobilität und Verkehr 2010; Bundesamt für Statistik BFS: Neuchâtel (CH), 2010.

32. BFS Eidgenössische Volkszählung (VZ); Bundesamt für Statistik BFS: Neuchâtel (CH), 2000.

33. BFS Mobilität in der Schweiz - Ergebnisse des Mikrozensus 2005 zum Verkehrsverhalten; Bundesamt für Statistik BFS: Neuchâtel (CH), 2005.

34. Holland, J. H., Adaptation in Natural and Artificial Systems: An Introductory Analysis with Applications to Biology, Control, and Artificial Intelligence. MIT Press Cambridge, MA (USA), 1992.

35. Iman, R. L.; Davenport, J. M.; Zeigler, D. K. Latin hypercube sampling (program user's guide); Sandia Laboratories: Texas (TX), 1980.

36. Kruskal, W., Use of ranks in one-criterion variance analysis. Journal of the American Statistical Association 1952, 47, 583-621.

37. Backhaus, K.; Erichson, B.; Plinke, W.; Weiber, R., Multivariate Analysemethoden. SpringerVerlag: Berlin, 2006; Vol. 11.

38. IPCC Contribution of Working Group I to the Fourth Assessment Report of the Intergovernmental Panel on Climate Change; IPCC: New York, NY, 2007.

39. Jungbluth, N.; Itten, R.; Stucki, M. Umweltbelastungen des privaten Konsums und Reduktionspotenziale; Federal Office for the Environment FOEN: Ittigen (CH), 2012. 
671 40. Goedkoop, M.; Heijungs, R.; Huijbregts, M. A. J.; Schryver, A. D.; Struijs, J.; Zelm, R. V. ReCiPe $672 \quad 2008 ; 2009$.

673 41. Frischknecht, R.; Steiner, R.; Jungbluth, N. Methode der ökologischen Knappheit 674 Ökofaktoren 2006; 0906; Bundesamt für Umwelt BAFU: Berne (CH), 2009.

675 42. Firebaugh, G., Empirics of World Income Inequality. American Journal of Sociology 1999, $676104,1597-1630$.

677 43. John, V. Derivation of reliable simplification strategies for the comparative LCA of 678 individual and "typical" newly built Swiss apartment buildings. ETH Zurich, Zurich (CH), 2012.

679 44. BFS Die Raumgliederungen der Schweiz; Bundesamt für Statistik BFS: Neuchâtel (CH), 2005. 680 45. Girod, B.; De Haan, P., More or Better? A Model for Changes in Household Greenhouse Gas 681 Emissions due to Higher Income. Journal of Industrial Ecology 2010, 14, 31-49.

682 46. Girardin, L.; Marechal, F.; Dubuis, M.; Calame-Darbellay, N.; Favrat, D., EnerGis: A 683 geographical information based system for the evaluation of integrated energy conversion systems 684 in urban areas. Energy 2010, 35, 830-840.

685

686 